\title{
Peripartum Hysterectomy: Is There Any Difference Between Emergency and Planned Surgeries?
}

\section{Histerectomia periparto: Existe alguma diferença entre as cirurgias de emergência e planejada?}

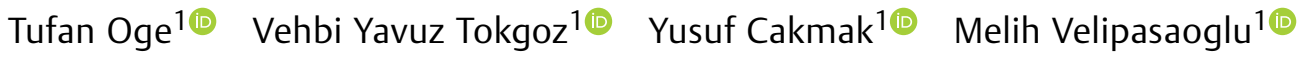 \\ ${ }^{1}$ Department of Obstetrics and Gynecology, School of of Medicine, \\ Eskisehir Osmangazi University, Eskisehir, Turkey \\ Rev Bras Ginecol Obstet 2022;44(1):3-9.

\begin{abstract}
Address for correspondence Vehbi Yavuz Tokgoz, Associate Professor, Department of Obstetrics and Gynecology, School of Medicine, Eskisehir Osmangazi University, Eskisehir, Turkey
\end{abstract} \\ (e-mail: mdtokgoz@hotmail.com).
}

\begin{abstract}
Keywords

- abnormal placentation

- emergency

- peripartum hysterectomy

- planned

- uterine atony
\end{abstract}

\section{Resumo}

received

February 21, 2020

accepted

August 9, 2021
Objective To compare the outcomes of emergency and planned peripartum hysterectomies.

Methods The present retrospective cross-sectional study was conducted in two hospitals. Maternal and neonatal outcomes were compared according to emergency and planned peripartum hysterectomies.

Results A total of 34,020 deliveries were evaluated retrospectively, and 66 cases of peripartum hysterectomy were analyzed. Of these, 31 were cases of planned surgery, and 35 were cases of emergency surgery. The patients who underwent planned peripartum hysterectomy had a lower rate of blood transfusion $(83.9 \%$ versus $100 \%$; $p=0.014)$, and higher postoperative hemoglobin levels $(9.9 \pm 1.3$ versus $8.3 \pm 1.3$; $p<0.001)$ compared with the emergency hysterectomy group. The birth weight was lower, although the appearance, pulse, grimace, activity, and respiration (Apgar) scores were higher in the planned surgery group compared with the emergency cases.

Conclusion Planned peripartum hysterectomy with an experienced team results in less need for transfusion and improved neonatal outcomes compared with emergency peripartum hysterectomy.

Objetivo Comparar os resultados das histerectomias periparto de emergência e planejada.

Métodos Este estudo transversal retrospectivo foi realizado em dois hospitais. Os resultados maternos e neonatais foram comparados de acordo com as histerectomias periparto de emergência e planejada.

Resultados Um total de 34.020 partos foram avaliados retrospectivamente, e 66 casos de histerectomia periparto foram analisados. Destes, 31 eram casos de cirurgias planejadas, e 35 , cirurgias de emergência. As pacientes que foram submetidas à
DOI https://doi.org/

10.1055/s-0041-1736303. ISSN 0100-7203. (c) 2022. Federação Brasileira de Ginecologia e Obstetrícia. All rights reserved.

This is an open access article published by Thieme under the terms of the Creative Commons Attribution License, permitting unrestricted use, distribution, and reproduction so long as the original work is properly cited. (https://creativecommons.org/licenses/by/4.0/)

Thieme Revinter Publicações Ltda., Rua do Matoso 170, Rio de Janeiro, RJ, CEP 20270-135, Brazil 
Palavras-chave

- placentação anormal

- de emergência

- histerectomia periparto

- planejada

- atonia uterina histerectomia periparto planejada tiveram uma taxa menor de transfusão de sangue ( $83,9 \%$ versus $100 \% ; p=0,014)$, e níveis mais elevados de hemoglobina pós-operatória $(9,9 \pm 1,3$ versus $8,3 \pm 1,3 ; p<0,001)$ em comparação com o grupo de histerectomia de emergência. $O$ peso ao nascer foi menor, embora as pontuações na escala de aparência, frequência cardíaca, irritabilidade reflexa, tônus muscular, e respiração (appearance, pulse, grimace, activity, and respiration, Apgar, em inglês) fossem maiores no grupo da cirurgia planejada em comparação com os casos de emergência.

Conclusão A histerectomia periparto planejada com uma equipe experiente resulta em menos necessidade de transfusão e melhora os resultados neonatais em relação à histerectomia periparto de emergência.

\section{Introduction}

Peripartum hysterectomy (PPH) is an important surgical procedure that is typically used to prevent maternal mortality from uterine hemorrhage and sepsis. It was first performed at the end of the nineteenth century as a life-saving procedure. ${ }^{1}$ The incidence of PPH varies between 0.2 and 6.09 for every thousand deliveries. ${ }^{2,3}$ The important risk factors for PPH are age, previous cesarean sections, previous uterine surgery, labor induction, abnormalities in placental invasion, and uterine atony. ${ }^{4,5}$ Recent studies $^{3,6}$ have reported that the most common indication for PPH was placental invasion anomalies, although uterine atony and uterine rupture were the most frequent reasons to perform $\mathrm{PPH}$ in the past. ${ }^{7,8}$ The increasing trend in cesarean sections might change the indications in favor of anomalies in placental invasion. ${ }^{9}$ Most PPH procedures are performed in an unplanned or emergency situation to prevent life-threatening hemorrhage after unsuccessful conservative approaches such as prostaglandins, tamponade, and compression sutures within 24 hour of a delivery. The morbidity or mortality rates increase with unprepared conditions such as lack of surgical experience and insufficient blood transfusion. Contrary to that, prenatally diagnosed and planned cesarean hysterectomy provides results in low intraoperative bleeding and complications. ${ }^{10}$ It also enables surgeons to prepare safe surgical procedures, to prevent morbidities with no increase in intra-/postoperative complications. ${ }^{11}$ The aim of the present study was to compare the intra-, postoperative, and neonatal outcomes of patients who underwent emergency or planned PPHs.

\section{Methods}

The present retrospective study was conducted in the Departments of Obstetrics and Gynecology of two hospitals (one tertiary center, and one government hospital) over a period of 23 years. The study was approved by the Research Ethics Committee of the School of Medicine of Eskisehir Osmangazi University (Ref. No: E.98130-2019/19). All women who underwent PPH were included in the study population. Peripartum hysterectomy was defined as hysterectomy performed after 24 weeks of gestation and at the time, or within 24 hours, of delivery. The data of the patients were collected from the medical records, which were reviewed for maternal characteristics such as age, gravidity, parity, gestational age, previous cesarean delivery, and mode of delivery. The preoperative laboratory parameters and indications for surgery were also recorded. The exclusion criteria were as follows: delivery before 24 weeks of gestation and hysterectomy after 24 hours of delivery. The type of the surgery, the intraoperative and postoperative complications, such as ureteral injury, bladder injury, retroperitoneal hematoma, nerve injury, and vessel injury, were investigated. The transfusion of blood products such as red blood cells and fresh frozen plasma performed during and after surgery were measured. The neonatal outcomes were also evaluated, such as birth weight and appearance, pulse, grimace, activity, and respiration (Apgar) scores. The patients were divided into the emergency and planned PPH groups, and the data were compared according to this categorization. Emergency PPH are performed in cases of uncontrollable bleeding with conservative treatment modalities, such as prostaglandins, oxytocics and baloon tamponade. Emergency hysterectomies are performed especially in cases of uncontrollable bleeding and shock, or in cases of previous hemodynamic or hemostatic restoration. Moreover, any type of vascular control is performed with an emergency hysterectomy if necessary. Planned PPH was defined as planned cesarean hysterectomy generally scheduled between the 34th and 37th weeks of gestation. We scheduled planned PPH with a dedicated team composed of an experienced gynecologic oncologist and a maternal-fetal medicine specialist. A preoperative evaluation was performed to determine the specific markers of abnormal placentation with the use of gray-scale and Doppler ultrasound. We administered antenatal corticosteroids before 34 weeks. We performed a midline vertical incision, and the uterus was incised at the fundus. The uterine incision was closed, and dissection of the retroperitoneum and bladder was carefully performed by an experienced surgical team that included a gynecologic oncologist. As much as possible, total abdominal hysterectomy was the main approach, but subtotal hysterectomy was performed in some cases.

The Statistical Package for the Social Sciences (SPSS, SPSS, Inc., Chicago, IL, United States) software, version 15.0, was 
used to analyze the data. Demographic parameters and clinical outcomes were analyzed with mean \pm standard deviation (SD) and median values. The Kolmogorov-Smirnov normality test was used to evalute the distribution of the parameters. Normally distributed data were analyzed by using independent samples $t$-test. The Mann-Whitney $U$ test was used to compare the non-parametric continuous and categorical data. The percentages were compared with the Pearson Chi-squared test or the Fisher Exact test. Values of $p<0.05$ were considered statistically significant.

\section{Results}

There were 34,020 deliveries during the study period. A total of 66 PPHs were performed, with an incidence of 1.9 for every thousand deliveries, and all cases of PPH were analyzed. The mean age of the patients was $31.3 \pm 5.5$ years. The gravidity ranged from 1 to 12 , with a mean of $3.9 \pm 2.4$. The average gestational age was $35.7 \pm 3.7$ weeks. Of these 66 patients, 14 (21.2\%) women delivered vaginally, and 52 (78.8\%) women underwent cesarean sections. Half of the patients $(n=33$; $50 \%$ ) had at least 1 previous cesarean section. The most common indications for PPH among the sample were placenta accreta $(n=26 ; 39.4 \%)$ and uterine atony $(n=20$; $30.3 \%)$. Overall, 24 (36.4\%) patients underwent subtotal abdominal hsyterectomy, and 42 (63.6\%) patients, total abdominal hysterectomy. Planned PPHs were performed in 31 (47\%) patients, while emergency PPHs were performed in 35 (53\%) cases. - Table 1 summarizes the demographic and clinical parameters of the emergency and planned PPH groups. The mean gestational age was significantly lower in the planned PPH group $(p=0.002)$. Moreover, more than $90 \%(n=28)$ of the patients in the planned group delivered after 34 gestational weeks. The indications for PPH among the study groups are shown in - Table $\mathbf{2}$. Uterine atony was the most common indication in the emergency group, whereas abnormal placentation was the most common indication in the planned group (57.1\%, $n=20$ and $67.7 \%$, $n=21$ respectively). We compared the blood transfusions, postoperative laboratory values, and intraoperative complications of both groups (-Table 3). The planned PPH group required the use of a significantly lower amount of blood products in the intra- and postoperative periods. The postoperative hemoglobin $(\mathrm{Hb})$ and the differences in pre- and

Table 1 Demographic and preoperative parameters of the groups submitted toemergency and planned hysterectomies

\begin{tabular}{|c|c|c|c|}
\hline & $\begin{array}{l}\text { Emergency hysterectomy } \\
(n=35)\end{array}$ & $\begin{array}{l}\text { Planned hysterectomy } \\
(n=31)\end{array}$ & $p$-value \\
\hline Age (years) & $31.9 \pm 6.5$ & $30.5 \pm 4.1$ & 0.18 \\
\hline Gravidity & $3.9 \pm 2.6$ & $4.1 \pm 2.1$ & 0.36 \\
\hline Parity & $2.9 \pm 2.6$ & $2.6 \pm 1.8$ & 0.94 \\
\hline Mean gestational age (weeks) & $36.3 \pm 4.9$ & $35.2 \pm 1.8$ & 0.002 \\
\hline \multicolumn{4}{|l|}{ Gestational age (weeks) - n(\%) } \\
\hline$<28$ & $2(6.3)$ & $0(0)$ & 0.169 \\
\hline $28-34$ & $5(15.6)$ & $3(9.7)$ & \\
\hline$>34$ & $25(78.1)$ & $28(90.3)$ & \\
\hline \multicolumn{4}{|l|}{ Mode of delivery - n(\%) } \\
\hline Vaginal delivery & $14(40)$ & $0(0)$ & 0.001 \\
\hline Cesarean delivery & $21(60)$ & $31(100)$ & \\
\hline Previous cesarean section - n(\%) & $7(20.0)$ & $26(83.9)$ & 0.001 \\
\hline Preoperative hemoglobin (g/dL) & $10.1 \pm 2.2$ & $10.8 \pm 1.2$ & 0.10 \\
\hline Preoperative hematocrit (\%) & $32.1 \pm 5.8$ & $32.4 \pm 3.0$ & 0.84 \\
\hline Preoperative platelet count $\left(\times 10^{9} / \mathrm{L}\right)$ & $222.0 \pm 73.6$ & $203.2 \pm 58.5$ & 0.30 \\
\hline
\end{tabular}

Table 2 Indications for peripartum hysterectomy

\begin{tabular}{llll}
\hline & $\begin{array}{l}\text { Emergency hysterectomy } \\
(\boldsymbol{n}=35)\end{array}$ & $\begin{array}{l}\text { Planned hysterectomy } \\
(\boldsymbol{n}=31)\end{array}$ & $\begin{array}{l}\text { Overall } \\
(\boldsymbol{n}=\mathbf{6 6 )}\end{array}$ \\
\hline Uterine atony $-\mathrm{n}(\%)$ & $20(57.1)$ & $0(0)$ & $20(30.3)$ \\
Uterine rupture $-\mathrm{n}(\%)$ & $9(25.7)$ & $0(0)$ & $9(13.6)$ \\
Placenta previa $-\mathrm{n}(\%)$ & $1(2.9)$ & $2(6.5)$ & $3(4.5)$ \\
Placenta accreta $-\mathrm{n}(\%)$ & $5(14.3)$ & $21(67.7)$ & $26(39.4)$ \\
Placenta percreta $-\mathrm{n}(\%)$ & $0(0)$ & $8(25.8)$ & $8(12.1)$ \\
\hline
\end{tabular}


6 Peripartum Hysterectomy: Difference between Emergency and Planned Surgeries Oge et al.

Table 3 Intra- and postoperative outcomes of the patients submitted to emergency and planned hysterectomies

\begin{tabular}{|c|c|c|c|}
\hline & $\begin{array}{l}\text { Emergency hysterectomy } \\
(n=35)\end{array}$ & $\begin{array}{l}\text { Planned } \\
\text { hysterectomy } \\
(n=31)\end{array}$ & $p$-value \\
\hline Red blood cell transfusion - $\mathrm{n}(\%)$ & $35(100)$ & $26(83.9)$ & 0.014 \\
\hline $\begin{array}{l}\text { Number of red blood cell transfusions } \\
\text { (units) }\end{array}$ & $6.0 \pm 5.0$ & $3.9 \pm 3.7$ & 0.06 \\
\hline Fresh frozen plasma transfusion - $\mathrm{n}(\%)$ & $34(97.1)$ & $23(74.2)$ & 0.007 \\
\hline $\begin{array}{l}\text { Number of fresh frozen plasma transfusions } \\
\text { (units) }\end{array}$ & $5.9 \pm 5.4$ & $2.5 \pm 2.1$ & 0.001 \\
\hline Postoperative hemoglobin $(\mathrm{g} / \mathrm{dL})$ & $8.3 \pm 1.3$ & $9.9 \pm 1.3$ & $<0.001$ \\
\hline Postoperative platelet count $\left(\times 10^{9} / \mathrm{L}\right)$ & $119.0 \pm 55.8$ & $158.3 \pm 44.3$ & 0.12 \\
\hline Difference between pre- and postoperative hemoglobin ( $\mathrm{g} / \mathrm{dL})$ & $1.7 \pm 1.5$ & $0.9 \pm 0.7$ & 0.03 \\
\hline $\begin{array}{l}\text { Difference between pre- and postoperative hemoglobin } \\
\text { (after transfusions; } \mathrm{g} / \mathrm{dL} \text { ) }\end{array}$ & $7.8 \pm 5.9$ & $4.8 \pm 4.6$ & 0.02 \\
\hline Vessel injury - n(\%) & $0(0)$ & $0(0)$ & 1 \\
\hline Nerve injury - $\mathrm{n}(\%)$ & $1(3)$ & $0(0)$ & 0.39 \\
\hline Retroperitoneal hematoma - n(\%) & $1(3)$ & $0(0)$ & 0.40 \\
\hline Bladder injury - n(\%) & $4(11)$ & $14(45)$ & 0.38 \\
\hline Ureteral injury - n(\%) & $0(0)$ & $1(3)$ & 0.39 \\
\hline Duration of hospital stay (days) & $8.2 \pm 5.9$ & $6.9 \pm 3.5$ & 0.57 \\
\hline
\end{tabular}

Table 4 Neonatal outcomes of the sample

\begin{tabular}{llll}
\hline & $\begin{array}{l}\text { Emergency hysterectomy } \\
(\boldsymbol{n}=35)\end{array}$ & $\begin{array}{l}\text { Planned hysterectomy } \\
(\boldsymbol{n}=31)\end{array}$ & $p$-value \\
\hline Birth weight $(\mathbf{g})$ & $3041 \pm 1186$ & $2564 \pm 491$ & 0.003 \\
Apgar scores & & & \\
1 minute & $4.9 \pm 3.4$ & $7.5 \pm 1.9$ & 0.001 \\
5 minutes & $6.5 \pm 3.9$ & $9.2 \pm 1.1$ & 0.006 \\
\hline
\end{tabular}

postoperative $\mathrm{Hb}$ values were also significantly different between the study groups. The complication rates were similar in both groups. The duration of the hospital stay was shorter in the planned group, but it did not reach statistical significance. - Table 4 shows that the neonatal outcomes were significantly different between the groups. The mean birth weight was significantly lower in the planned group, and it might be related to the earlier gestational week at the time of the surgery. Although we have demonstrated the lower birth weight in the planned group, the Apgar scores of this group were significantly better than those of the emergency group $(p<0.01)$.

\section{Discussion}

The present study showed that the most common indication for PPH was placenta accreata, a subgroup of placental invasion anomalies. The planned PPHs resulted in a lower rate of morbidities and better neonatal outcomes compared with the emergency procedures, which, in turn, required a greater amount of blood products.
The incidence of PPH varies widely. In a large-scaled metaanalysis, ${ }^{6}$ the incidence found was of 0.9 for every thousand deliveries. A retrospective cohort study ${ }^{12}$ from Pakistan showed a higher incidence, of 4.01 for every thousand deliveries. We have also observed PPH with an incidence of 1.7 for every thousand deliveries in a previous study from our tertiary center. ${ }^{13}$ There are several studies that have assessed PPHs, and the incidence may change among countries and centers depending on whether they have sufficient antenatal care for pregnancies. In some studies ${ }^{7,14-17}$ from Turkey, the incidence of PPH was established between 0.3 and 5.38 for every thousand deliveries. Sharma et al. $^{3}$ found a much higher incidence, of 6.9 for every thousand deliveries. The incidence found in the present study was similar to those found in previous studies, and in accordance with other Turkish studies. ${ }^{11,13,14,21,23}$ In the past, the most common indication used to be uterine atony. ${ }^{7,8}$ However, recently, the main indication has been shifted from uterine atony to abnormal placentation. ${ }^{18}$ The rising rates of cesarean delivery may result in placental pathologies, increasing the rates of PPH. ${ }^{6,19-21}$ In a study published in 2016, van den Akker 
et al. $^{6}$ evaluated $\sim 8$ million deliveries, and reported that placental abnormalities were the most common indication for $\mathrm{PPH}$, followed by uterine atony. In a recent study, Kazi ${ }^{12}$ found that emergency PPH was performed in cases of hemorrhage primarily due to uterine atony. Senturk et al. ${ }^{17}$ suggested that the incidence of PPH was higher in Eastern Turkey, and the main indication was uterine atony and rupture. The increasing use of uterotonics and rate of cesarean sections may explain the shift on the main indication for $\mathrm{PPH}$ from uterine atony to abnormal invasive placentation. 3,6,19,22-24 Morbidly adherent placenta has gained prominent as an indication, especially in planned cesarean $\mathrm{PPH}^{3}$ Briery et al. ${ }^{11}$ reported that uterine atony was the indication for emergency PPH in over half of the patients, and placenta accreta was the second most frequent indication. In a retrospective study, Sharma et al. $^{3}$ showed that placenta accreta was observed in all of the elective PPH patients. We found similar results in accordance to the recent literature. $^{3,6,11,12,17}$ The rate of cesarean sections has increased over the years; in the present study, it was of $63.6 \%$. Therefore, placental abnormalities were present in $56 \%$ of patients. We have also determined that the indication for PPH was only abnormal placental pathologies in the planned group. We have performed total abdominal hysterectomy in $63.6 \%$ ( $n=42$ ) of the patients, with no significant differences between both study groups. Subtotal hysterectomy is more desirable for surgeons, because removal of the cervix may be difficult due to possible dilation in cases of PPH. As aforementioned, total abdominal hysterectomy was performed more frequently in the present study. Some studies ${ }^{7,20}$ have demonstrated that subtotal abdominal hysterectomy is more suitable, especially in cases of abnormalities in placental invasion, and the morbidity was lower than that of cases of total abdominal hysterectomy. However, some researchers $^{5,8}$ have suggested the performance of total abdominal hysterectomy if the patient is in good condition, and they have indicated that this procedure should be considered to prevent hemorrhage from the cervix.

Studies $^{8,11}$ have established that intraoperative bleeding is higher in cases of emergency PPH compared with scheduled cases. In a recent prospective-cohort study, Seoud et al. $^{25}$ have observed lower volumes of intraoperative bleeding in the elective surgery group, and they have also found that a lower amount of blood products were transfused in the elective cases. In parallel with the higher blood loss, there is a higher amount of transfused blood products in $\mathrm{PPH}$. In the present study, we observed that all of the patients in the emergency group received red blood cell transfusions, and transfusions were necessary in $83.9 \%(n=26)$ of the planned surgery group $(p=0.014)$. We have also determined that lower volumes of fresh frozen plasma transfusion were required in the planned group. Wei et al. ${ }^{26}$ reported a rate of $95 \%$ of red blood cell transfusion, and Sak et al. ${ }^{27}$ reported a rate of $62.2 \%$ among placenta accreta patients. Briery et al. ${ }^{11}$ compared the rates of transfusion of red blood cells between patients undergoning emergency and planned cesarean hysterectomies, and they observed rates of $66 \%$ and $33 \%$, with a mean of 4.5 and 1.6 of transfused units respectively $(p<0.05)$. Seoud et al., ${ }^{25}$ in their prospective-cohort study, also found that elective surgery was associated with lower rates of blood transfusion compared with emergency surgery. ${ }^{25}$ In another retrospective study, ${ }^{3}$ the authors reported lower postoperative $\mathrm{Hb}$ values in the emergency surgery group compared with the planned group, but without statistical significance $(7.8 \pm 1.6$ versus $8.9 \pm 2.2$ respectively; $p=0.08$ ). In the present study, we have also found significantly lower levels of $\mathrm{Hb}$ in the emergency group. The transfused units of red blood cells and fresh frozen plasma were higher in the emergency group. Similar to our study, Seoud et al. ${ }^{25}$ established that the transfusion rate and mean transfused units were higher in the emergency cases. We have also analyzed the difference between preoperative and postoperative $\mathrm{Hb}$ levels, and found lower differences in the planned cases compared with emergency cases. A higher rate of complications is expected in the emergency PPH group. Bladder injury, which is the most common complication, ranges from $3 \%$ to $20 \%$ in several studies. $3,7,12,17,23$ In the present study, the incidence of bladder injury $(27.2 \%, n=18)$ was higher than that reported in the literature, and the planned group had a higher rate of bladder injury than emergency group, but this was not statistically significant. We believe that the higher rate may be related to the higher incidence of abnormal placental invasion in the planned group. Briery et al. ${ }^{11}$ reported a higher incidence of postoperative complications in the group submitted to emergency cesarean hysterectomy. Two studies ${ }^{11,25}$ have established that the length of the hospital stay was similar between the two groups, but Pettit et al. ${ }^{28}$ reported a shorter hospital stay in the planned group. We have also observed a slightly longer hospital stay in the emergency group, which was not statistically significant, and was similar to the literature findings.

Neonatal outcomes are important in PPHs. In emergency procedures, these outcomes may be affected negatively, so we can improve the neonatal outcomes by performing planned PPHs in selected patients with proper timing. Seoud et al. ${ }^{25}$ reported similar birth weight and Apgar scores among elective and emergency cases. Pettit et al. ${ }^{28}$ also compared the neonatal outcomes and reported similar Apgar scores for both groups. Otherwise, they found later gestational weeks and higher birth weights in the planned group. Briery et al. ${ }^{11}$ reported that the planned group had later gestational weeks, and higher fetal birth weight and Apgar scores compared with the emergency group, which were not statistically significant. On the contrary, we have observed significantly later gestational weeks and higher birth weight in the emergency group. We have also observed significantly higher Apgar scores in the planned group, although their gestational weeks were later, and the birth weight, lower than those of the emergency group. A possible explanation for that may be administration of antenatal corticosteroids to all of the patients in the planned group prior to delivery.

Emergency PPH is a life-saving procedure, but it results in some postoperative problems. Thus, planned PPH may improve the maternal and neonatal outcomes and decrease the complication rates. The prenatal diagnosis of abnormal placental invasion becomes significant for the performance 
scheduled surgery. One third of the cases of placental accreta diagnosed prenatally still delivered in an unplanned manner. ${ }^{28}$ We think that it is not possible to completely avoid emergency cases. The ideal delivery time for cases of suspected abnormal placentation is still controversial. There were more optimal outcomes regarding the cases of placenta accreta with delivery at the 34 th gestational week..$^{29}$ The American College of Obstetricians and Gynecologists (ACOG) recently recommended delivery at 34 weeks to 35 weeks and 6 days, especially in cases of suspected placenta accreta. ${ }^{30}$ The ACOG also suggests performing the deliveries in cases of placenta accreta with an expert team in a tertiary center. ${ }^{10}$

The main limitation of the present study was its retrospective nature. The data of the study population covers a very wide time interval, so cases of uterine atony were more present in older data, and cases of placental pathologies were more prominent in the more recent data. This might establish a selection bias for the present study. However, in the present study, we have comprehensively compared emergency and planned PPHs, and the size of the sample was not large enough according to previous studies..$^{15,16,28}$ One of the limitations is the lack of information about the level of expertise of the surgeons in both study groups. Another important limitation is that we have compared different indications for emergency and planned surgeries, such as uterine atony and anomalies in placental invasion; since in cases of uterine atony, the uterine anatomy is not distorted compared to placental invasion anomalies such as placenta accreata.

\section{Conclusion}

We have shown that planning the PHP prenatally improved the maternal and neonatal outcomes. The prenatal diagnosis of suspected cases provides some surgical preparations such as ureteral catheter placement during the surgery. According to the aforementioned ACOG recommendations, we make an effort to diagnose the suspected cases prenatally, and we also currently perform planned PHPs from 34 weeks to 35 weeks and 6 days of gestation with an expert multi-disciplinary team. Further prospective studies are needed to investigate the correlation of planned PHP and perinatal outcomes.

\section{Contributors}

All authors participated in the concept and design of the study, as well as in the analysis and interpretation of data, draft or revision of the manuscript, and they have approved the manuscript as submitted. All authors are responsible for the reported research.

\section{Conflict of Interests}

The author have no conflict of interests to declare.

\section{References}

1 Sturdee DW, Rushton DI. Caesarean and post-partum hysterectomy 1968-1983. Br J Obstet Gynaecol. 1986;93(03):270-274. Doi: 10.1111/j.1471-0528.1986.tb07906.x

2 Umezurike CC, Feyi-Waboso PA, Adisa CA. Peripartum hysterectomy in Aba southeastern Nigeria. Aust N Z J Obstet Gynae- col. 2008;48(06):580-582. Doi: 10.1111/j.1479-828X.2008. 00905.x

3 Sharma B, Sikka P, Jain V, Jain K, Bagga R, Suri V. Peripartum hysterectomy in a tertiary care hospital: Epidemiology and outcomes. J Anaesthesiol Clin Pharmacol. 2017;33(03):324-328. Doi: 10.4103/joacp.JOACP_380_16

4 Cho GJ, Kim LY, Hong HR, Lee CE, Hong SC, Oh MJ, et al. Trends in the rates of peripartum hysterectomy and uterine artery embolization. PLoS One. 2013;8(04):e60512. Doi: 10.1371/journal.pone.0060512

5 Zelop CM, Harlow BL, Frigoletto FD Jr, Safon LE, Saltzman DH. Emergency peripartum hysterectomy. Am J Obstet Gynecol. 1993; 168(05):1443-1448. Doi: 10.1016/s0002-9378(11)90779-0

6 van den Akker T, Brobbel C, Dekkers OM, Bloemenkamp KWM. Prevalence, indications, risk indicators, and outcomes of emergency peripartum hysterectomy worldwide: a systematic review and meta-analysis. Obstet Gynecol. 2016;128(06):1281-1294. Doi: 10.1097/AOG.0000000000001736

7 Zeteroglu S, Ustun Y, Engin-Ustun Y, Sahin G, Kamaci M. Peripartum hysterectomy in a teaching hospital in the eastern region of Turkey. Eur J Obstet Gynecol Reprod Biol. 2005;120(01):57-62. Doi: 10.1016/j.ejogrb.2004.08.011

8 Chestnut DH, Eden RD, Gall SA, Parker RT. Peripartum hysterectomy: a review of cesarean and postpartum hysterectomy. Obstet Gynecol. 1985;65(03):365-370

9 Langhoff-Roos J, Chantraine F, Geirsson RT. AIP (abnormally invasive placenta)-from a retained placenta to destruction of the uterine wall. Acta Obstet Gynecol Scand. 2013;92(04): 367-368. Doi: 10.1111/aogs.12112

10 Committee on Obstetric Practice. Committee opinion no. 529: placenta accreta. Obstet Gynecol. 2012;120(01):207-211. Doi: 10.1097/AOG.0b013e318262e340

11 Briery CM, Rose CH, Hudson WT, Lutgendorf MA, Magann EF, Chauhan SP, et al. Planned vs emergent cesarean hysterectomy. Am J Obstet Gynecol. 2007;197(02):154.e1-154.e5

12 Kazi S. Emergency peripartum hysterectomy: A great obstetric challenge. Pak J Med Sci. 2018;34(06):1567-1570. Doi: 10.12669/ pjms.346.13686

13 Velipasaoglu M, Senturk M, Tanir HM. [Emergency peripartum hysterectomy: 20-year experience of a University Hospital]. Akd Med J.. 2017;3(03):165-169. Doi: 10.17954/amj.2017.89, Turkish.

14 Tapisiz OL, Altinbas SK, Yirci B, Cenksoy P, Kaya AE, Dede S, et al. Emergency peripartum hysterectomy in a tertiary hospital in Ankara, Turkey: a 5-year review. Arch Gynecol Obstet. 2012;286 (05):1131-1134. Doi: 10.1007/s00404-012-2434-z

15 Yalinkaya A, Güzel AI, Kangal K. Emergency peripartum hysterectomy: 16-year experience of a medical hospital. J Chin Med Assoc. 2010;73(07):360-363. Doi: 10.1016/S1726-4901(10)70078-2

16 Güngördük K, Yildirim G, Dugan N, Polat I, Sudolmus S, Ark C. Peripartum hysterectomy in Turkey: a case-control study. J Obstet Gynaecol. 2009;29(08):722-728. Doi: 10.3109/0144361090316 8358

17 Senturk MB, Cakmak Y, Guraslan H, Dogan K. Emergency peripartum hysterectomy: 2-year experiences in non-tertiary center. Arch Gynecol Obstet. 2015;292(05):1019-1025. Doi: 10.1007/ s00404-015-3740-z

18 Huque S, Roberts I, Fawole B, Chaudhri R, Arulkumaran S, ShakurStill H. Risk factors for peripartum hysterectomy among women with postpartum haemorrhage: analysis of data from the WOMAN trial. BMC Pregnancy Childbirth. 2018;18(01):186. Doi: 10.1186/s12884-018-1829-7

19 Flood KM, Said S, Geary M, Robson M, Fitzpatrick C, Malone FD. Changing trends in peripartum hysterectomy over the last 4 decades. Am J Obstet Gynecol. 2009;200(06):632.e1-632.e6. Doi: 10.1016/j.ajog.2009.02.001

20 Sahin S, Guzin K, Eroğlu M, Kayabasoglu F, Yaşartekin MS Emergency peripartum hysterectomy: our 12-year experience. Arch Gynecol Obstet. 2014;289(05):953-958. Doi: 10.1007/ s00404-013-3079-2 
21 Hsu YR, Kung FT, Roan CJ, Ou CY, Hsu TY. Emergency peripartum hysterectomy due to placenta previa/accreta: 10 years' experience. Taiwan J Obstet Gynecol. 2004;43(04):206-210

22 Hernandez JS, Wendel GD Jr, Sheffield JS. Trends in emergency peripartum hysterectomy at a single institution: 1988-2009. Am J Perinatol. 2013;30(05):365-370. Doi: 10.1055/s-0032-1324704

23 Arulpragasam K, Hyanes G, Epee-Bekima M. Emergency peripartum hysterectomy in a Western Australian population: Ten-year retrospective case-note analysis. Aust N Z J Obstet Gynaecol. 2019;59(04):533-537. Doi: 10.1111/ajo.12922

24 Rahman J, Al-Ali M, Qutub HO, Al-Suleiman SS, Al-Jama FE, Rahman MS. Emergency obstetric hysterectomy in a university hospital: A 25-year review. J Obstet Gynaecol. 2008;28(01): 69-72. Doi: 10.1080/01443610701816885

25 Seoud MA, Nasr R, Berjawi GA, Zaatari GS, Seoud TM, Shatila AS et al. Placenta accreta: Elective versus emergent delivery as a major predictor of blood loss. J Neonatal Perinatal Med. 2017;10 (01):9-15. Doi: 10.3233/NPM-1622

26 Wei Q, Zhang W, Chen M, Zhang L, He G, Liu X. Peripartum hysterectomy in 38 hospitals in China: a population-based study.
Arch Gynecol Obstet. 2014;289(03):549-553. Doi: 10.1007/ s00404-013-3002-x

27 Sak S, Barut M, Incebiyik A, Uyanikoglu H, Hilali N, Sak M. Management of peripartum hysterectomies performed on patients with placenta percreta in a tertiary central hospital. J Matern Fetal Neonatal Med. 2019;32(06):883-888. Doi: $10.1080 / 14767058.2017 .1394289$

28 Pettit KE, Stephenson ML, Truong YN, Henry D, Murphy A, Kim L, et al; University of California Fetal Consortium. Maternal and neonatal outcomes among scheduled versus unscheduled deliveries in women with prenatally diagnosed, pathologically proven placenta accreta. J Matern Fetal Neonatal Med. 2019;32(06): 927-931. Doi: 10.1080/14767058.2017.1395847

29 Robinson BK, Grobman WA. Effectiveness of timing strategies for delivery of individuals with placenta previa and accreta. Obstet Gynecol. 2010;116(04):835-842. Doi: 10.1097/AOG.0b013e3181 f3588d

30 Silver RM, Fox KA, Barton JR, Abuhamad AZ, Simhan H, Huls CKet al. Center of excellence for placenta accreta. Am J Obstet Gynecol. 2015; 212(05):561-568. Doi: 10.1016/j.ajog.2014.11.018 